Original research article

\title{
The effect of genetic counseling on depression, anxiety, and knowledge level among diabetes mellitus patients
}

\author{
Henri Setiawan ${ }^{1,2}{ }^{*}$, Yudisa Diaz Lutfi Sandi ${ }^{3}$, Esti Andarini ${ }^{4}$, Rudi Kurniawan ${ }^{1}$, \\ Selvia David Richard ${ }^{5}$, Heri Ariyanto ${ }^{1}$ \\ ${ }^{1}$ STIKes Muhammadiyah Ciamis, Department of Nursing, West Java, Indonesia \\ ${ }^{2}$ Fujian Medical University, School of Nursing, Fujian, China \\ ${ }^{3}$ Akademi Keperawatan Pemerintah Kabupaten Ngawi, Department of Nursing, East Java, Indonesia \\ ${ }^{4}$ Southern Medical University, School of Nursing, Guangzhou, China \\ ${ }^{5}$ STIKes RS Baptis Kediri, Department of Nursing, East Java, Indonesia
}

\begin{abstract}
Aim: The aim of the research was to demonstrate the effect of genetic counseling on depression, anxiety and knowledge level among diabetes mellitus patients.

Design: Quasi-experimental study.

Methods: A quantitative study that used a questionnaire instrument to assess participants' levels of depression, anxiety, and knowledge. A total of 38 diabetes mellitus patients who met the inclusion criteria were studied for two months at the Lakbok Public Health Center with genetic counseling. Outcomes were measured before and after the counseling intervention provided. The statistical analysis was performed using the IBM SPSS version 25.0 software.

Results: The results showed that the majority of participants (76.3\%) had moderate depression prior to the genetic counseling intervention. However, after the intervention, most of the participants $(73.7 \%)$ experienced mild depression, with a change in mean \pm standard deviation (SD) pre-post $26.3 \pm 3.1$ to $17.6 \pm 2.6$. The anxiety level of most participants was moderate (73.7\%). After the intervention, most participants experienced mild anxiety (86.8\%) with a change in mean \pm SD $16.7 \pm 3.3$ to $11.3 \pm 2.3$. In addition, before the intervention the knowledge level of the majority of the participants was satisfactory (86.8\%). After the intervention, the knowledge level of the majority of the participants became good (52.6\%) with a change in the mean \pm SD of $12.8 \pm 1.4$ to $16.1 \pm 2.3$.

Conclusions: Changes in the level of depression, anxiety and knowledge in different categories are real evidence of the consistency of the intervention's effect on these very significant factors that have implications for health services in various health facilities such as hospitals and public health centers. Therefore, serious efforts are needed so that health policies encourage the presence of genetic counseling services for DM patients and patients of other genetic diseases.
\end{abstract}

Keywords: Anxiety; Depression; Diabetes mellitus; Genetic counseling; Knowledge

\section{Introduction}

Diabetes mellitus (DM) is a chronic disease caused by metabolic disorders that requires serious treatment (Setiawan et al., 2018). Although DM is a genetic disease, it is not difficult to find it in Indonesia and even around the world. Through its official website, the World Health Organization (WHO) states that the prevalence of DM sufferers increased by $4.7 \%$ in 1980 to $8.5 \%$ in 2014 , with a $5 \%$ increase in premature mortality between 2000 and 2016 (WHO, 2020). Furthermore, DM cases in Indonesia continue to increase, with the country now ranking 6 th in the world. The Indonesian government, via the official website of the Ministry of Health (MoH), explains that DM is the highest cause of death after stroke and coronary heart disease. If not handled seriously, this number will continue to increase and could threaten the health status of the public in the future (P2PTM, 2018).

DM occurs due to disruption of the endocrine system in the pancreas which causes reduced insulin production. As a result, glucose cannot enter the cells and accumulate in the blood. This condition can be influenced by various factors, including the role of genetics. Polymorphisms are found in several genes that have links to insulin secretion mechanisms and metabolic processes such as the SLC22A1 gene located on chromosome 11q12.3 (Firdaushty et al., 2020), TNF-alpha located on chromosome 6p21.33 (Ayelign et al., 2019), TCF7L2 which is located on chromosome 10q25.2-q25.3, KCNJ11 which is locat-

\footnotetext{
* Corresponding author: Henri Setiawan, STIKes Muhammadiyah Ciamis, jln. KH. Ahmad Dahlan no. 20, Ciamis 46216, West Java, Indonesia; e-mail: henrisetiawan1989@gmail.com

http://doi.org/10.32725/kont.2021.035

Submitted: 2021-05-01 • Accepted: 2021-08-04 • Prepublished online: 2021-08-06 
ed on chromosome 11p15.1 (Dedoussis et al., 2007), HLA-II which is located on chromosome $6 \mathrm{p} 21$, and INS which is located on chromosome 11p15.5 (Redondo et al., 2018), etc.

Gene polymorphisms need to receive intensive therapy over a long period of time. Apart from being able to cause severe clinical manifestations, polymorphism can be passed on to the next generation with inheritance patterns that follow Mendel's law, including autosomal recessive, autosomal dominant, X-linked recessive and X-linked dominant (Bull, 2013). Neonatal DM (NDM) or Maturity Onset Diabetes of the Young (MODY) is inherited autosomal dominant which carries a risk of more than $50 \%$. However, the inheritance pattern in DM, especially Type 1 and 2 DM (T1DM or T2DM), cannot be clearly ascertained because it is not only caused by genetic interactions involving more than 1 gene (polygenic); the influence of lifestyle and the environment is also quite strong. For this reason, patients and families need to have a comprehensive understanding of the disease, prognosis and treatment management (Philipson, 2017).

As a counselor, nurses can provide genetic counseling (GC) as the right choice of intervention. They provide information about the disease (education) as well as counseling on the management and modifications to lifestyle and environment (Setiawan et al., 2020). Although genetic factors strongly influence DM, other risk factors such as nutritional compliance, resting patterns, stress management, sports activities and other healthy lifestyles must be strictly watched (Rahim et al., 2020).

GC is a communication process that aims to help clients and families understand and adapt to the genetic diseases they are suffering from. In addition to basic knowledge about genetic diseases and their therapeutic management, GC traces the patient's family members by making family pedigrees of three generations. Thus, a counselor will be able to calculate the recurrent risk in the next generation. Diagnostic screening and testing options are clearly explained in the counseling session, until behavior and lifestyle modifications are decided in that session (Carlson et al., 2019; Setiawan et al., 2020; Yang and Kim, 2018).

In Indonesia, GC is not well known to the public or healthcare providers. The capability of nurses to be counselors is still very limited. This is due to the unavailability of a genetic nurse college and the lack of education in becoming a genetic specialist nurse. Not all hospitals, public health centers and nursing clinics provide GC services specifically. In fact, GC has a big role in overcoming the physical and psychosocial problems caused by genetic diseases such as diabetes mellitus (Rujito and Ghozali, 2010).

Physically, DM can cause hyperglycemia, weakness, polyphagia, polyuria, polydipsia, weight loss, blurred vision, yeast infection, etc. (Mayega and Rutebemberwa, 2018). In this condition, the patient needs comprehensive information and knowledge. Various risk factors that can worsen and cause complications such as coronary heart disease, chronic kidney failure and ketoacidosis must be avoided (Balaji et al., 2019). So family and environmental support is needed in overcoming the health problems experienced by patients (Yamin and Sari, 2018).

Another impact of DM are the psychological aspects such as insomnia, poor concentration, and depressed mood (Khan et al., 2019). Research shows the level of depression in diabetes sufferers is still high, namely more than $20 \%$ with a variety of categories, from mild, moderate to severe (Andreoulakis et al., 2012). Similar to depression, the majority of DM patients experience other psychological problems in the form of anxi- ety at a mild level (66.5\%), followed by mild to moderate level of anxiety (21.1\%) (Nawaz et al., 2018).

The emergence of depression and anxiety in DM patients is closely related to the lack of disease control, hospitalization, prognosis and complication, socio-economics, quality of life impairment and lack of family support (Andreoulakis et al., 2012; Harista and Lisiswanti, 2015). If this psychological problem is not handled properly, it will worsen the condition of the DM patient. In theory, this is caused by a process of increased secretion and counter-regulatory hormone action, changes in glucose transport function, and increased inflammatory activation (Harista and Lisiswanti, 2015).

Based on this background, DM patients need genetic counseling intervention to test its effect on the level of depression, anxiety and patient knowledge.

\section{Materials and methods}

\section{Study design}

A quasi experimental study was conducted to examine the effect of genetic counseling on depression, anxiety and knowledge level among diabetes mellitus patients.

\section{Participants in the study}

This research was conducted with a non-probability sampling method (accidental sampling). Out of 631 people with DM, 38 were selected that met the criteria. The inclusion criteria were people with diabetes who were outpatients at the Lakbok health center and were able to write and read. The exclusion criteria were patients who had complication from other chronic diseases and who refused to participate. The characteristics of the participants involved can be seen in Table 2 .

\section{Intervention}

All participants involved in this study received genetic counseling intervention and referred to the module compiled by the experts. Genetic counseling is carried out by a researcher and assisted by a nurse. It takes place over several stages, namely pre-counseling, inter-counseling, psychological assessment, discussion, decision making, session closing and post-counseling. Table 1 provides detailed information on the genetic counseling process that is carried out.

\section{Measurements}

The instrument used in this study was a questionnaire consisting of four parts, including socio demographics, depression level, anxiety and knowledge. The socio demographics section is a multiple choice question about the characteristics of the participants - which include age, gender, education, occupation and the length of time they have been experiencing diabetes.

The second part is a questionnaire that measures depression level using the Beck Depression Inventory II (BDI-II), a very popular measurement tool for describing a person's depression (Beck et al., 1996). BDI-II consists of 21 items to estimate the intensity of depression in people who are physically healthy or sick (Setiawan et al., 2017). Each item consists of four statements that indicate certain symptoms of depression (Sorayah, 2015). BDI-II has been translated into Indonesian and tested for validity $(p<0.01)$ and reliability (alpha cronbach coefficient 0.90) (Ginting et al., 2013). The range of scores for each item was $0-4$, with the criteria for a score of 0-13 including the normal category, 14-19 in the mild depression catego- 
Table 1. Summary of intervention protocol

\begin{tabular}{|c|c|}
\hline Phase & Summary of intervention \\
\hline Pre-counseling & $\begin{array}{l}\text { Prepare the necessary information } \\
\text { Review health records that are relevant to genetic problems experienced by participants } \\
\text { Re-discuss the health conditions of participants with relevant health personnel } \\
\text { Prepare information to be provided with appropriate educational aids, in the form of flipcharts } \\
\text { and leaflets }\end{array}$ \\
\hline \multicolumn{2}{|l|}{ Inter-counseling } \\
\hline Opening/Information greetings & $\begin{array}{l}\text { Greetings } \\
\text { Inviting participants to sit in the place that has been prepared } \\
\text { Confirming the identity of participants } \\
\text { Asking about health conditions }\end{array}$ \\
\hline Introduction & $\begin{array}{l}\text { Saying thank you for his/her attendance } \\
\text { Introducing yourself } \\
\text { Asking family members who suffer from DM }\end{array}$ \\
\hline Diagnosis & Explaining the purpose of genetic counseling \\
\hline Information gathering & $\begin{array}{l}\text { Asking information about the cause of the disease that the doctor diagnosed } \\
\text { Explaining the definitions, epidemiology, ethiology, pathophysiology, classification, clinical } \\
\text { manifestation, therapy, prognosis and prevention of DM } \\
\text { Identifying the family pedigree } \\
\text { Calculating the recurrent risk in the next generation (calculation of recurrent risk) }\end{array}$ \\
\hline Psychological assessment & $\begin{array}{l}\text { Observing the psychological response of participants during genetic counseling or answering } \\
\text { the questions given }\end{array}$ \\
\hline Discussion & $\begin{array}{l}\text { Confirming the ability of participants to absorb the information provided } \\
\text { Providing the opportunity to ask questions about information that is unclear }\end{array}$ \\
\hline Decision making & $\begin{array}{l}\text { Asking about the next plan } \\
\text { Asking family members about screening test options } \\
\text { Asking about a commitment to maintaining a healthy lifestyle }\end{array}$ \\
\hline Session closing & $\begin{array}{l}\text { Ongoing support with a contact number or email address } \\
\text { Saying thank you } \\
\text { Closing }\end{array}$ \\
\hline Post-counseling & $\begin{array}{l}\text { Evaluating the implementation of the intervention } \\
\text { Recording documentation of the implementation of genetic counseling }\end{array}$ \\
\hline
\end{tabular}

ry, 20-28 in the moderate depression category, and a score of 29-63 in the severe depression category.

The Indonesian version of the Hamilton Anxiety Rating Scale (HARS) was used to measure the participants' level of anxiety. The value of the validity of the Pearson correlation is 0.529-0.727, while the reliability value of Cronbach's alpha is 0.756 (Ramdan, 2019). The number of questions in this questionnaire were 14 items with a range of answer options from $0-4$. Interpretation of the results can be grouped into no anxiety or normal $0-6$, mild anxiety $7-14$, moderate anxiety $15-27$ and severe anxiety $>27$.

The Public Knowledge Scale of Diabetes Mellitus (PKS$\mathrm{DM}$ ) is a questionnaire developed by researchers to measure the level of participants' knowledge about DM. The validity test shows the value of $r>0.05$ with alpha reliability of 0.84 (Chiptarini, 2014). The questionnaire is in the form of 20 statement items with true and false choices. The score for each correct item is 1 point, while if it is wrong it is 0 points. Knowledge classification refers to the theory developed by Arikunto (2010) which is divided into 3 levels, namely good (if the score is $>76 \%$ or 15.2 points), satisfactory (if the score is between $56-76 \%$ or $11.2-15.1$ points), and less (if the score is $<56 \%)$.

\section{Data collection}

All participants involved filled out an informed consent form and a questionnaire. Data were collected with the assistance of an enumerator - from the time the study began to up to two weeks after the intervention was given (1 December 2020 14 February 2021). The questionnaire was administered using the Google Form online platform. All of the filled data is automatically stored in the Google Form cloud and it can be converted to the Microsoft Excel application. The pre-test was carried out at the time before the intervention was given on the same day. The post-test was carried out two weeks after the intervention. Researchers checked all questionnaire sheets to ensure all questions were answered completely. Participants who withdrew during the study could withdraw their data at any time.

\section{Statistical analysis}

Data processing was performed using the IBM SPSS version 25.0 software. All the obtained data were checked in relation to identity and completeness based on the questionnaire's answer sheet. Descriptive statistical analysis was carried out to show the frequency, percentage, mean and standard deviation of the socio demographic variables. Meanwhile, the parametric 
statistical analysis used the Kolmogorov-Smirnov test to assess the normality in the data based on the variables of depression, anxiety and knowledge. The effect of the intervention on the outcome variables was analyzed using the Wilcoxon test.

\section{Results}

\section{Characteristics of the participants}

Table 2 shows detailed information about the participants' socio demographic status. The age range of participants was from 43-82 years, the majority of the group were elderly adults (51-60 years) (42.1\%), and women (68.4\%) with a high school education (44.7\%). Most of the participants worked as farmers $(28.9 \%)$. The DM pain was mostly experienced in $1-5$ years (42.1\%).

Table 2. Characteristics of the participants

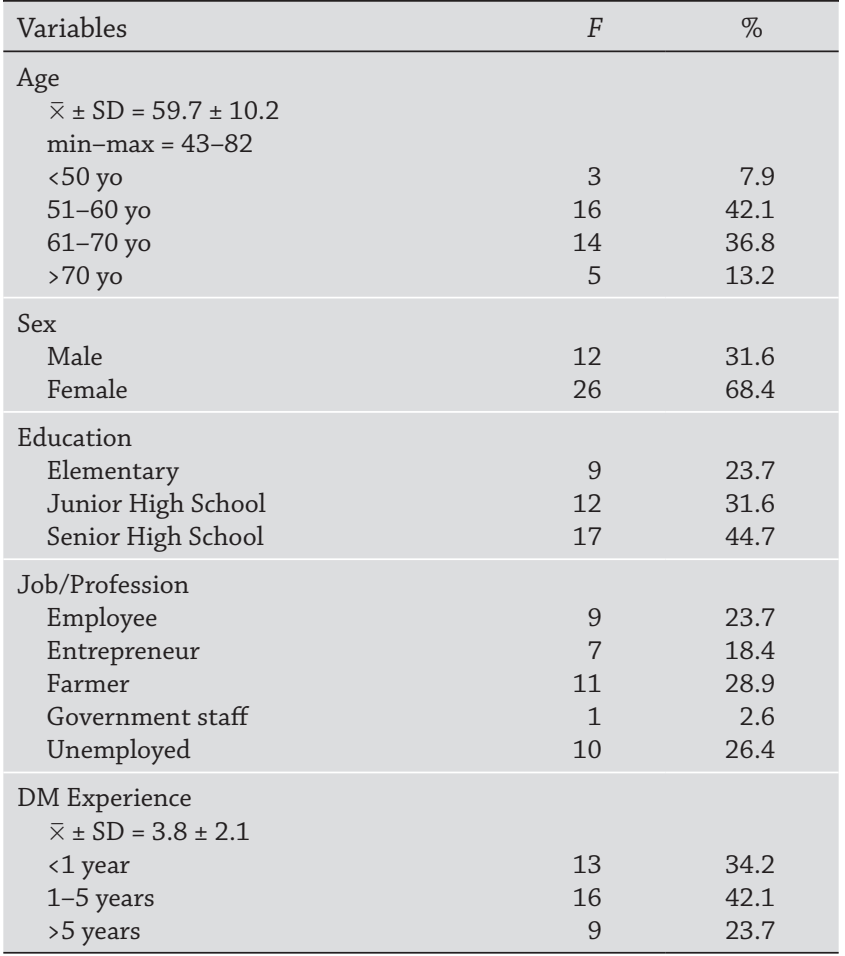

\section{Descriptive statistic variables in pre-post intervention}

Table 3 shows detailed information about changes in scores on the independent variables - including depression status, anxiety and participant knowledge - both before and after the intervention. The results showed that the majority of participants experienced moderate depression (76.3\%) prior to the genetic counseling intervention. However, after receiving the intervention, the majority of participants experienced only mild depression $(73.7 \%)$ with a change in mean \pm standard deviation (SD) pre-post $26.3 \pm 3.1$ to $17.6 \pm 2.6$. The anxiety level of most participants was moderate anxiety (73.7\%). After the intervention, the majority of participants experienced mild anxiety $(86.8 \%)$ with a change in mean \pm SD $16.7 \pm 3.3$ to $11.3 \pm 2.3$. In addition, before the intervention the knowledge level of the majority of the participants was satisfactory (86.8\%). After the intervention, the majority of participants' knowledge became good (52.6\%) with a change in the mean \pm SD of $12.8 \pm 1.4$ to $16.1 \pm 2.3$.
Changes in the level of depression, anxiety and participant knowledge before and after the intervention showed an effect of the intervention on the outcome. To measure the effect of the intervention in terms of size $(Z)$ and significance $(p)$, the Wilcoxon test was carried out ( results are shown in Table 4).

In the depression and anxiety variables, the lower (negative change) the questionnaire score is, the better the respondent's condition; thus the $\mathrm{Z}$ score becomes negative. Whereas the knowledge variable applies the opposite, so that the $Z$ value is positive if conditions improve compared to what they were previously. The Wilcoxon test results show the $Z$ value on all outcome variables $>1.0$ with $p$-value $=0.000$. This shows that the effect of genetic counseling interventions on the outcome is very strong - with a very high level of significance. This is indicated by all outcome variables experiencing positive ranks $>50 \%$ (depression $=89.5 \%$, anxiety $=63.3 \%$, and knowledge $=$ $55.3 \%)$. It was only in the anxiety variable where there was one respondent (2.6\%) who experienced negative ranks.

\begin{tabular}{|c|c|c|c|c|c|c|}
\hline \multirow{2}{*}{ Variables } & \multicolumn{3}{|c|}{ Pre-test } & \multicolumn{3}{|c|}{ Post-test } \\
\hline & $F$ & $\%$ & $\bar{x} \pm S D$ & $F$ & $\%$ & $\bar{x} \pm S D$ \\
\hline \multicolumn{7}{|l|}{ Depression } \\
\hline Normal & 0 & 0.0 & $26.3 \pm 3.1$ & 0 & 0.0 & $17.6 \pm 2.6$ \\
\hline Mild & 0 & 0.0 & & 28 & 73.7 & \\
\hline Moderate & 29 & 76.3 & & 10 & 26.3 & \\
\hline Severe & 9 & 23.7 & & 0 & 0.0 & \\
\hline \multicolumn{7}{|l|}{ Anxiety } \\
\hline Normal & 0 & 0.0 & $16.7 \pm 3.3$ & 0 & 0.0 & $11.3 \pm 2.3$ \\
\hline Mild & 10 & 26.3 & & 33 & 86.8 & \\
\hline Moderate & 28 & 73.7 & & 5 & 13.2 & \\
\hline Severe & 0 & 0.0 & & 0 & 0.0 & \\
\hline \multicolumn{7}{|l|}{ Knowledge } \\
\hline Good & 4 & 10.5 & $12.8 \pm 1.4$ & 20 & 52.6 & $16.1 \pm 2.3$ \\
\hline Satisfactory & 33 & 86.8 & & 18 & 47.4 & \\
\hline Less & 1 & 2.6 & & 0 & 0.0 & \\
\hline
\end{tabular}

\begin{tabular}{|c|c|c|c|c|c|c|c|c|}
\hline \multirow{2}{*}{ Variables } & \multicolumn{2}{|c|}{$\begin{array}{l}\text { Positive } \\
\text { rank }\end{array}$} & \multicolumn{2}{|c|}{$\begin{array}{c}\text { Negative } \\
\text { rank }\end{array}$} & \multicolumn{2}{|c|}{ Ties } & \multirow[t]{2}{*}{ Z } & \multirow{2}{*}{$p$} \\
\hline & $F$ & $\%$ & $F$ & $\%$ & $F$ & $\%$ & & \\
\hline Depression & 34 & 89.5 & 0 & 0.0 & 4 & 10.5 & (-) 5.6 & 0.000 \\
\hline Anxiety & 24 & 63.2 & 1 & 2.6 & 13 & 34.2 & (-) 4.6 & 0.000 \\
\hline Knowledge & 21 & 55.3 & 0 & 0.0 & 17 & 44.7 & 4.4 & 0.000 \\
\hline
\end{tabular}

\section{Discussion}

This study aims to assess the effect of GC in individuals with diabetes mellitus on depression, anxiety, and knowledge variables. Researchers compared levels of depression, anxiety, and knowledge before and after the intervention. All of these variables are measured by instruments that are in accordance with the results and the research hypothesis $(p=0.000, \mathrm{Z}>1.0)$. The results showed that genetic counseling interventions had a significant effect - and so should be considered in a number of evidence-based studies (Athens et al., 2017).

\section{Depression}

Prior to the genetic counseling intervention of 38 participants, 9 participants reported high levels of depression, 29 partic- 
ipants reported moderate levels of depression. However, after receiving the GC intervention, 10 participants reported moderate levels of depression, 28 participants reported mild depression. Overall, the majority of participants reported positive changes, indicating that genetic counseling interventions had a significant effect in reducing depression levels in individuals with DM. Findings in the field show the impact of disease education, emotional support and motivation (which are given during GC sessions) on reducing depression levels in DM sufferers. This can be proven by the change in the mean value of depression in the first measurement (before the intervention), which is 26.3 , and in the second measurement (after the intervention) the mean value of depression has decreased to 17.6 with $p$ value $=0.000(Z=-5.6)$. Changes in depression status that occur are part of changes in perceptions of risk which can be influenced by cognitive, social, and cultural factors (Leblond et al., 2011).

The level of depression in DM patients can cause symptoms of increased anxiety status, which is influenced by genetic risk perception, therapy management, and disease prognosis (Cicero et al., 2017). Several participants previously had depressive symptoms that were high in the severe and moderate categories. The effect of psychological reactions is related to information received and subjective perceptions about a person's risk of disease (Godino et al., 2016). This proves that the counseling process could resolve psychosocial problems for sufferers of diabetes through discussion methods and problem orientation (Eijzenga et al., 2014; Montgomery et al., 2013; Nishigaki et al., 2014). Another statement reveals that genetic counseling can be used as a motivational enhancement approach and emotional support in diabetics (Nishigaki et al., 2014). Facilitating such discussions can have many positive effects, including increasing physicians' awareness of their patients' problems, improving patient problem management, increasing patient satisfaction, and improving health indicators (Street et al., 2009). Ideally, such matters should be recognized and discussed during genetic counseling (Riley et al., 2012) through health education methods, which, during counseling, are very helpful in clearing bad feelings - both directly and via telecommunications media (Schwartz et al., 2014; Yee et al., 2014).

\section{Anxiety}

Before the 38 participants were given genetic counseling intervention, 28 participants reported moderate anxiety levels, whilst 10 participants reported mild anxiety levels. However, after being given genetic counseling intervention, 5 participants reported moderate anxiety levels, and 33 participants reported mild anxiety levels. Overall, the majority of participants reported positive changes, suggesting that genetic counseling interventions have a significant effect in reducing anxiety levels in individuals with DM disease. This can be proven by the change in the average value of anxiety in the first measurement (before the intervention), which is 16.7, and in the second measurement (after the intervention) in which the average value of anxiety has decreased to 11.3 with $p$ value $=$ 0.000 .

The large proportion of anxiety levels before being given genetic counseling intervention indicate high levels of anxiety, and the genetic risk variants found so far only serve to explain a small proportion of anxiety disorders (Manolio et al., 2009). When DM sufferers pay attention to the genetic risk that will be experienced by their descendants it can increase symptoms of depression and anxiety (Cicero et al., 2017). Anxiety-causing factors include unpleasant life events as an adult, such as chronic or acute illness, loss, separation events, experiences of threats or financial problems (Faravelli, 1985; Faravelli and Pallanti, 1989; Faravelli et al., 2007; Scocco et al., 2006). After the intervention, respondents reported lower anxiety levels. Information and discussion conducted during face to face genetic counseling increase the knowledge on the disease and reduce anxiety levels in individuals (Jenkins et al., 2007; Proctor and Hayes, 2017). This study is in line with research that shows that telephone counseling interventions can have a positive impact on the psychological functioning of people with diabetes (Graves et al., 2010). Another argument states that genetic counseling about DM for healthy adults with a family history of type 2 diabetes shows a positive effect in modifying the negative perceived control ability for DM - without causing a psychological burden which is defined as anxiety (Nishigaki et al., 2014).

\section{Knowledge}

Before the 38 participants were given the genetic counseling intervention, 1 participant reported a lack of knowledge, 33 participants reported a satisfactory level of knowledge, 4 participants reported a good level of knowledge. However, after being given the genetic counseling intervention, 18 participants reported a satisfactory level of knowledge, whilst 20 participants reported a good level of knowledge. Overall, the majority of participants reported positive changes, indicating that genetic counseling interventions had a significant effect on changes in knowledge levels in individuals with DM disease. This can be proven by the change in the average value of knowledge in the first measurement (before the intervention), namely 12.8, and the second measurement (after the intervention) in which the average value of knowledge increased to 16.1 with a $p$ value $=0.000$.

According to the results of the study, genetic counseling intervention had a significant effect. One part of the genetic counseling intervention was education about DM (Roshanai et al., 2009). Genetic counseling sessions are highly valuable for increasing knowledge and enhancing psychosocial function, and so should be understood as part of best nursing practice (Blue et al., 2015). In addition, genetic counseling provides significant changes in individuals in increasing knowledge and satisfaction in understanding information related to family history experiences with DM disease (Madlensky et al., 2017).

The results of other studies supported our findings on the risk information regarding DM disease - which was explained during a genetic counseling session for DM at a medical examination center. This could help DM sufferers and families with a history of DM to understand and control the disease through lifestyle modification (Nishigaki et al., 2014). In fact, people receive genome profiling and intervention based on their genotype, their lifestyle, and the actions they can take to prevent DM, which is influenced by their self-understanding on the risk factor for DM (Arkadianos et al., 2007; Bloss et al., 2011).

The results of the causal analysis indicate that there is consistent significance of all the variables studied, legitimizing the hypothesis we have developed. In particular, the quasi-experimental analysis of genetic counseling intervention had a significantly lower effect on the level of anxiety. The level of depression is in line with the decrease of anxiety felt by the individual. It is inseparable from the individual's knowledge after they received genetic counseling, which involves the provision of information, discussion, psychosocial approaches, decision making and the introduction of subjective predictors. This is intended to suppress the early symptoms of anxiety and depression caused by the lack of the individual's knowledge. 


\section{Clinical implications}

The findings from the study have implications for health policy in supporting the application of genetic counseling in every health service, especially during the treatment of patients with genetic diseases such as DM. Although there are many studies on genetic counseling and its benefits, genetic counseling is more widely available in several hospitals located in major cities in Indonesia. In regional or district public hospitals, most health workers are not familiar with genetic counseling intervention services (Rujito and Ghozali, 2010; Setiawan et al., 2017). In addition, the lack of knowledge or information about genetic diseases among ordinary people and health practitioners hinders the genetic counseling process. This results in many health practitioners who lack confidence in providing genetic counseling (Grant et al., 2013).

Access and genetic counseling services can be carried out directly or indirectly by utilizing technological development in the 4.0 era. Service modification can use telemedicine, telenursing, or telecounseling models using the telephone communication tools, websites, or applications (Bradbury et al., 2018; Fan et al., 2017; Schwartz et al., 2014). Thus patients can have intensive interactive communication during the stay at home. Remote consultation between patients and a health worker or genetic counselor supports performance indicators and expected outcome criteria during the treatment process.

\section{Study limitations}

The research undertaken evaluates the psychosocial impact and level of knowledge over a short period. Respondents were only evaluated once, right after receiving the intervention. This limits the possible effect of the intervention on patient's health status over a longer period of time in subsequent years. Long-term measurements would ascertain the extent to which genetic counseling is carried out and its effects on other variables that are interconnected by exploring the patient's perceived experiences.

The limited-time for the study was caused by the intervention process, which was carried out directly by only two researchers. Nurses who work in the research location did not have sufficient information about genetic counseling services so that they cannot be involved. For this reason, in the future, serious efforts are needed to increase the knowledge and competence of nurses in the implementation of genetic counseling. This will support the optimization of the role of nurses as educators as well as counselors (Tomatir et al., 2006).

\section{Conclusions}

Genetic counseling has a very significant effect on the psychosocial status and knowledge level of DM patients ( $p$ value $=$ $0.000, Z>1.00)$. The level of depression and anxiety showed a very significant decrease after the intervention. Participants reported a mean level of depression of $26.3 \pm 3.1$ to $17.6 \pm 2.6$. It was similar with anxiety, which was originally $16.7 \pm 3.3$ to $11.3 \pm 2.3$. Meanwhile, positive changes occurred at the level of knowledge from $12.8 \pm 1.4$, which increased to $16.1 \pm 2.3$.

Changes in the level of depression, anxiety, and knowledge in various categories are clear evidence of the consistency of the effect of the intervention on all variables, and this has implications for health services in various health facilities such as hospitals and public health centers. Therefore, serious efforts are needed to ensure that health policies encourage the presence of genetic counseling services for DM patients and other genetic diseases.

\section{Ethical aspects and conflict of interests}

The authors have no conflict of interests to declare.

\section{Ethical approval}

All participants received an explanation of the purpose of the study and agreed to participate by signing an informed consent. This research is authorized by the Institute for Research and Community Service (LPPM) STIKes Muhammadiyah Ciamis (with number 177/III.3.AU/F/2021), and the Office of National Unity and Community Protection (Kesbangpolinmas) Ciamis Regency (070.3/747/kesbangpol.03).

\section{Acknowledgements}

We would like to express our gratitude to the Public Health Center of Lakbok (Puskesmas Lakbok) and the Council of Higher Education, Research and Development of Muhammadiyah Central Leadership for their participation in this research. 


\section{Vliv genetického poradenství na depresi, úzkost a úroveň znalostí u pacientů $s$ onemocněním diabetes mellitus}

\section{Souhrn}

Cíl: Cílem výzkumu bylo prokázat vliv genetického poradenství na depresi, úzkost a úroveň znalostí u pacientů s onemocněním diabetes mellitus.

Design: Kvaziexperimentální studie.

Metody: Kvantitativní studie využívající dotazníkový nástroj k posouzení úrovně deprese, úzkosti a znalostí účastníků. Celkem 38 pacientů s diabetem mellitem, kteří splňovali kritéria pro zařazení do studie, bylo zkoumáno po dobu dvou měsíců ve veřejném zdravotnickém centru Lakbok s pomocí genetického poradenství. Výsledky byly měřeny před a po poskytnuté poradenské intervenci. Statistická analýza byla provedena pomocí softwaru IBM SPSS verze 25.0.

Výsledky: Výsledky ukázaly, že většina účastníků $(76,3 \%)$ trpěla před intervencí s pomocí genetického poradenství středně vážnou depresí. Po intervenci však většina účastníků $(73,7 \%)$ trpěla mírnou depresí, přičemž průměrná hodnota \pm směrodatná odchylka (SD) před intervencí činila $26,3 \pm 3,1$ a po intervenci $17,6 \pm 2,6$. Úroveň úzkosti většiny účastníků byla středně vážná (73,7 \%). Po intervenci většina účastníků pocitovala mírnou úzkost ( $86,8 \%)$ se změnou průměru \pm SD (z $16,7 \pm 3,3$ na $11,3 \pm 2,3)$. Před intervencí byla úroveň znalostí většiny účastníků uspokojivá ( 86,8 \%). Po intervenci se úroveň znalostí většiny účastníků zlepšila na 52,6\% (z 12,8 $\pm 1,4$ na 16,1 $\pm 2,3)$.

Závěr: Změny v úrovni deprese, úzkosti a znalostí v různých kategoriích jsou reálným důkazem konzistentnosti účinku zkoumané intervence na tyto velmi důležité faktory, které mají význam pro zdravotní služby v různých zdravotnických zařízeních, jako jsou nemocnice a veřejná zdravotnická střediska. Proto je třeba vyvinout maximální úsilí, aby zdravotní politika v budoucnu podporovala přítomnost služeb genetického poradenství pro pacienty s DM a pacienty s jinými genetickými chorobami.

Klíčová slova: deprese; diabetes mellitus; genetické poradenství; úzkost; znalosti

\section{References}

1. Andreoulakis E, Hyphantis T, Kandylis D, Iacovides A (2012). Depression in diabetes mellitus: a comprehensive review. Hippokratia 16(3): 205-214.

2. Arikunto S (2010). Prosedur Penelitian. Jakarta: Rineka Cipta.

3. Arkadianos I, Valdes AM, Marinos E, Florou A, Gill RD, Grimaldi KA (2007). Improved weight management using genetic information to personalize a calorie controlled diet. Nutr J 6: 29. DOI: 10.1186/1475-2891-6-29.

4. Athens BA, Caldwell SL, Umstead KL, Connors PD, Brenna E, Biesecker BB (2017). A Systematic Review of Randomized Controlled Trials to Assess Outcomes of Genetic Counseling. J Genet Couns 26(5): 902-933. DOI: 10.1007/s10897-0170082-y.

5. Ayelign B, Genetu M, Wondmagegn T, Adane G, Negash M, Berhane N (2019). Tnf- $\alpha$ (-308) Gene Polymorphism and Type 2 Diabetes Mellitus in Ethiopian Diabetes Patients. Diabetes Metab Syndr Obes 12: 2453-2459. DOI: 10.2147/DMSO. S229987.

6. Balaji, R, Duraisamy R, Kumar MPS (2019). Complications of diabetes mellitus: A review. Drug Invent Today, 12(1): 98-103.

7. Beck AT, Steer RA, Brown GK (1996). Manual for the Beck depression Inventory-II. San Antonio, TX: Psychological Corporation.

8. Bloss CS, Schork NJ, Topol EJ (2011). Effect of Direct-toConsumer Genomewide Profiling to Assess Disease Risk. N Engl J Med 364(6): 524-34. DOI: 10.1056/nejmoa1011893.

9. Blue GM, Kasparian NA, Sholler GF, Kirk EP, Winlaw DS (2015). Genetic counselling in parents of children with congenital heart disease significantly improves knowledge about causation and enhances psychosocial functioning. Int J Cardiol 178: 124-30. DOI: 10.1016/j.ijcard.2014.10.119.

10. Bradbury AR, Patrick-Miller LJ, Egleston BL, Hall MJ, Domchek SM, Daly MB, et al. (2018). Randomized Noninferiority Trial of Telephone vs In-Person Disclosure of Germline Cancer Genetic Test Results. J Natl Cancer Inst 110(9): 1-9. DOI: 10.1093/jnci/djy015.

11. Bull L (2013). Genetics, Mutations, and Polymorphisms. In: Madame Curie Bioscience Database [online] [cit. 2021-0411]. Available from: https://www.ncbi.nlm.nih.gov/books/ NBK6475/
12. Carlson LM, Harris S, Hardisty EE, Hocutt G, Vargo D, Campbell E, et al. (2019). Use of a novel computerized decision aid for aneuploidy screening: a randomized controlled trial. Genet Med 21(4): 923-929. DOI: 10.1038/s41436-018-0283-2.

13. Chiptarini IFD (2014). Gambaran Pengetahuan dan Perilaku Tentang Penatalaksanaan DM pada Pasien DM di Puskesmas Ciputat Timur. Jakarta: UIN Syarif Hidayatullah Jakarta.

14. Cicero G, De Luca R, Dorangricchia P, Lo Coco G, Guarnaccia C, Fanale D, et al. (2017). Risk Perception and Psychological Distress in Genetic Counselling for Hereditary Breast and/or Ovarian Cancer. J Genet Couns 26(5): 999-1007. DOI: 10.1007/s10897-017-0072-0.

15. Dedoussis GVZ, Kaliora AC, Panagiotakos DB (2007). Genes, diet and type 2 diabetes mellitus: A review. Rev Diabet Stud 4(1): 13-24. DOI: 10.1900/RDS.2007.4.13.

16. Eijzenga W, Aaronson NK, Hahn DEE, Sidharta GN, Van Der Kolk LE, Velthuizen ME, et al. (2014). Effect of routine assessment of specific psychosocial problems on personalized communication, counselors' awareness, and distress levels in cancer genetic counseling practice: A randomized controlled trial. J Clin Oncol 32(27): 2998-3004. DOI: 10.1200/ JCO.2014.55.4576.

17. Fan CW, Castonguay L, Rummell S, Lévesque S, Mitchell JJ, Sillon G (2017). Online Module for Carrier Screening in Ashkenazi Jewish Individuals Compared with In-Person Genetics Education : A Randomized Controlled Trial. J Genet Couns 27(2): 426-438. DOI: 10.1007/s10897-017-0133-4.

18. Faravelli $C$ (1985). Life events preceding the onset of panic disorder. J Affect Disord 9(1): 103-105. DOI: 10.1016/01650327(85)90016-3.

19. Faravelli C, Pallanti S (1989). Recent life events and panic disorder. Am J Psychiatr 146(5): 622-626. DOI: 10.1176/ ajp.146.5.622.

20. Faravelli C, Catena M, Scarpato A, Ricca V (2007). Epidemiology of life events: Life events and psychiatric disorders in the Sesto Fiorentino study. Psychother Psychosom 76(6): 361-368. DOI: $10.1159 / 000107564$.

21. Firdaushty R, Usman E, Linosefa L (2020). Gambaran Polimorfisme Gen SLC22A1 rs683369 pada Pasien Diabetes Melitus Tipe 2 yang Mendapatkan Terapi Metformin. Jurnal Kesehatan Andalas 9(15): 88-93. DOI: 10.25077/jka. v9i1s.1160.

22. Ginting H, Naring G, van der Veld WM, Srisayekti W, Becker ES (2013). Validating the Beck depression inventory-II in 
Indonesia's general population and coronary heart disease patients. Int J Clin Health Psychol 13(3): 235-242.

23. Godino L, Razzaboni E, Bianconi M, Turchetti D (2016). Impact of Genetic Counseling in Women with a Family History of Breast Cancer in Italy. J Genet Couns 25(2): 405-411. DOI: 10.1007/s10897-015-9884-y.

24. Grant RW, O’Brien KE, Waxler JL, Vassy JL, Delahanty LM, Bissett LG, et al. (2013). Personalized genetic risk counseling to motivate diabetes prevention: A randomized trial. Diabetes Care 36(1): 13-19. DOI: 10.2337/dc12-0884.

25. Graves KD, Wenzel L, Schwartz MD, Luta G, Wileyto P, Narod S, et al. (2010). Randomized controlled trial of a psychosocial telephone counseling intervention in BRCA1 and BRCA2 mutation carriers. Cancer Epidemiol Biomarkers Prev 19(3): 648-654. DOI: 10.1158/1055-9965.EPI-09-0548.

26. Harista RA, Lisiswanti R (2015). Depresi pada Penderita Diabetes Mellitus Tipe 2 Depression in. Majority 4(9): 73-77.

27. Jenkins J, Calzone KA, Dimond E, Liewehr DJ, Steinberg SM, Jourkiv O, et al. (2007). Randomized comparison of phone versus in-person BRCA1/2 predisposition genetic test result disclosure counseling. Genet Med 9(8): 487-495. DOI: 10.1097/ GIM.0b013e31812e6220.

28. Khan ZD, Lutale J, Moledina SM (2019). Prevalence of Depression and Associated Factors among Diabetic Patients in an Outpatient Diabetes Clinic. Psychiatry J 2019: 2083196. DOI: $10.1155 / 2019 / 2083196$.

29. Leblond D, Brédart A, Dolbeault S, De Pauw A, Lyonnet DS, Flahault C, Sultan S (2011). Cognitive, emotional and behavioral impact of an uncertain outcome after study of BRCA1/2: Review of the literature. Bulletin Du Cancer 98(2): 184-198. DOI: 10.1684/bdc.2011.1309.

30. Madlensky L, Trepanier AM, Cragun D, Lerner B, Shannon KM, Zierhut H (2017). A Rapid Systematic Review of Outcomes Studies in Genetic Counseling. J Genet Couns 26(3): 361-378. DOI: 10.1007/s10897-017-0067-x.

31. Manolio TA, Collins FS, Cox NJ, Goldstein DB, Hindorff LA, Hunter DJ, et al. (2009). Finding the missing heritability of complex diseases. Nature 461(7265): 747-753. DOI: 10.1038/ nature08494.

32. Mayega RW, Rutebemberwa E (2018). Clinical presentation of newly diagnosed diabetes patients in a rural district hospital in Eastern Uganda. Afr Health Sci 18(3): 707-719. DOI: 10.4314/ ahs.v18i3.29.

33. Montgomery SV, Barsevick AM, Egleston BL, Bingler R, Ruth K, Miller SM, et al. (2013). Preparing individuals to communicate genetic test results to their relatives: Report of a randomized control trial. Fam Cancer 12(3): 537-546. DOI: 10.1007/ s10689-013-9609-z.

34. Nawaz MS, Shah KU, Rashid HU, Mahmood S, Bukhsh A, Rehman IU, et al. (2018). Factors associated with anxiety in type 2 diabetes mellitus patients in Pakistan. Int J Diabetes Dev Ctries 38(3): 298-304. DOI: 10.1007/s13410-017-0591-0.

35. Nishigaki M, Tokunaga-Nakawatase Y, Nishida J, Kazuma K (2014). The Effect of Genetic Counseling for Adult Offspring of Patients with Type 2 Diabetes on Attitudes Toward Diabetes and its Heredity: A Randomized Controlled Trial. J Genet Couns 23(5): 762-769. DOI: 10.1007/s10897-013-9680-5.

36. P2PTM (Direktorat Pencegahan dan Pengendalian Penyakit Tidak Menular). Kementrian Kesehatan Republik Indonesia (2018). Lindungi Keluarga Dari Diabetes. [online] [cit. 2021-0411]. Available from: http://p2ptm.kemkes.go.id/post/lindungikeluarga-dari-diabetes

37. Philipson L (2017). Monogenic Diabetes (Neonatal Diabetes Mellitus \& MODY). [online] [cit. 2021-04-11]. Available from: https://www.niddk.nih.gov/health-information/diabetes/ overview/what-is-diabetes/monogenic-neonatal-mellitus-mody

38. Proctor G, Hayes C (2017). Counselling for Depression: a response to counselling education in the twenty-first century. Ethical conflicts between a counselling approach operating within a medicalised bureaucratic health service. $\mathrm{Br} \mathrm{J}$ Guid Couns 45(4): 1-10. DOI: 10.1080/03069885.2016.1274377.

39. Rahim FF, Abdulrahman SA, Maideen SFK, Rashid A (2020). Prevalence and factors associated with prediabetes and diabetes in fishing communities in Penang, Malaysia: A crosssectional study. PLoS ONE 15(2): 1-17. DOI: 10.1371/journal. pone. 0228570

40. Ramdan IM (2019). Reliability and Validity Test of the Indonesian Version of the Hamilton Anxiety Rating Scale (HAM-A) to Measure Work-related Stress in Nursing. Jurnal Ners 14(1): 33-40. DOI: 10.20473/jn.v14i1.10673.

41. Redondo MJ, Steck AK, Pugliese A (2018). Genetics of type 1 diabetes. Pediatr Diabetes 19(3): 346-353. DOI: 10.1111/ pedi.12597.

42. Riley BD, Culver JO, Skrzynia C, Senter LA, Peters JA, Costalas JW, et al. (2012). Essential elements of genetic cancer risk assessment, counseling, and testing: Updated recommendations of the National Society of Genetic Counselors. J Genet Couns 21(2): 151-161. DOI: 10.1007/ s10897-011-9462-x.

43. Roshanai AH, Rosenquist R, Lampic C, Nordin K (2009). Does enhanced information at cancer genetic counseling improve counselees' knowledge, risk perception, satisfaction and negotiation of information to at-risk relatives? A randomized study. Acta Oncol 48(7): 999-1009. DOI: 10.1080/02841860903104137.

44. Rujito L, Ghozali PA (2010). Menggagas Pengembangan Layanan Konseling Genetik di Unit Pelayanan Kesehatan: Sebuah Kajian Awal. Maj Kedokt Indon 60(9).

45. Schwartz MD, Valdimarsdottir HB, Peshkin BN, Mandelblatt J, Nusbaum R, Huang AT, et al. (2014). Randomized noninferiority trial of telephone versus in-person genetic counseling for hereditary breast and ovarian cancer. J Clin Oncol 32(7): 618-626. DOI: 10.1200/JCO.2013.51.3226.

46. Scocco P, Barbieri I, Frank E (2006). Interpersonal problem areas and onset of panic disorder. Psychopathology 40(1): 8-13. DOI: 10.1159/000096384.

47. Setiawan H, Ediati A, Winarni TI (2017). Genetic Counseling to Reduce the Level of Depression in Parents of Children with Thalassemia Major. In: 2nd International Conference on Sport Science, Health and Physiscal Education (ICSSHPE), pp. 102-106.

48. Setiawan H, Roslianti E, Firmansyah A (2020). Theory Development of Genetic Counseling among Patient with Genetic Diseases. IJNHS 3(6): 709-715. DOI: 10.35654/ijnhs. v3i6.350.

49. Setiawan H, Sopatilah E, Rahmat G, Wijaya DD, Ariyanto H (2018). Hubungan Tingkat Pengetahuan dengan Kecemasan Penderita Diabetes Mellitus. Proceeding The 7th University Research Colloqium 2018: Bidang MIPA dan Kesehatan, pp. 241-248.

50. Sorayah S (2015). Uji Validitas Konstruk Beck InventoryII (BDI-II). Jurnal Pengukuran Psikologi Dan Pendidikan Indonesia 4(1): 1-6. DOI: 10.15408/jp3i.v4i1.9259.

51. Street RL, Jr., Makoul G, Arora NK, Epstein RM (2009). How does communication heal? Pathways linking clinician-patient communication to health outcomes. Patient Educ Couns 74(3): 295-301. DOI: 10.1016/j.pec.2008.11.015.

52. Tomatir AG, Sorkun HC, Demirhan H, Akdag B (2006). Nurses' professed knowledge of genetics and genetic counseling. Tohoku J Exp Med 210(4): 321-332. DOI: 10.1620/tjem.210.321.

53. WHO - World Health Organization (2020). Diabetes: Overview. [online] [cit. 2021-04-11]. Available from: https://www.who. $\mathrm{int} /$ news-room/fact-sheets/detail/diabetes

54. Yamin A, Sari CWM (2018). Relationship of Family Support Towards Self-Management and Quality of Life of Patients with Type 2 Diabetes Mellitus. Jurnal Keperawatan Padjadjaran 6(2): 175-182. DOI: 10.24198/jkp.v6i2.673.

55. Yang M, Kim JW (2018). Principles of genetic counseling in the era of next-generation sequencing. Ann Lab Med 38(4): 291-295. DOI: 10.3343/alm.2018.38.4.291.

56. Yee LM, Wolf M, Mullen R, Bergeron AR, Cooper Bailey S, Levine R, Grobman WA (2014). A randomized trial of a prenatal genetic testing interactive computerized information aid. Prenatal Diagnosis 34(6): 552-557. DOI: 10.1002/pd.4347. 